\title{
Analisis Kesalahan Mahasiswa dalam Menyelesaikan Soal Interpolasi Berdasarkan Analisis Kesalahan Newman
}

\author{
Erwan Setiawan $^{1, *}$, Nia Jusniani ${ }^{2}$, Andi Sutandi ${ }^{3}$ \\ 1,2,3 Universitas Suryakancana \\ *erwan85setiawan@gmail.com
}

\begin{tabular}{|l|l|l|l|}
\hline Received : 15-07-2021 & Revised: 06-11-2021 & Accepted: 08-11-2021 & Published: 21-12-2021 \\
\hline
\end{tabular}

\begin{abstract}
ABSTRAK
Interpolasi merupakan salah satu metode numerik yang digunakan untuk memprediksi suatu nilai data yang tidak diketahui. Materi interpolasi sangat penting dikuasai dengan baik oleh mahasiswa, terutama untuk menunjang kegiatan penelitian dalam pengerjaan tugas akhir. Untuk mengetahui efektifitas dalam pembelajaran interpolasi di masa pandemi ini maka salah satu caranya perlu dilakukan analisis kesalahan. Melalui analisis kesalahan, dosen mengetahui bentuk-bentuk kesalahan yang paling sering dilakukan mahasiswa, sehingga dapat dijadikan pertimbangan untuk menerapkan strategi pembelajaran yang lebih efektif. Metode penelitian yang digunakan merupakan metode kualitatif dengan pendekatan deskriptif melalui analisis hasil jawaban mahasiswa terhadap soal Ujian Tengah Semester. Subjek penelitian adalah mahasiswa program studi pendidikan matematika FKIP Universitas Suryakancana yang mengampu mata kuliah metode numerik tahun akademik 2020 - 2021. Jumlah mahasiswa yang menjadi subjek penelitian sebanyak 20 orang. Hasil dari penelitian ini adalah kesalahan keterampilan proses merupakan bentuk kesalahan yang paling sering dilakukan mencapai $71 \%$ berdasarkan tahap analisis kesalahan Newman. Pada kelompok yang memiliki kemampuan pemecahan masalah rendah bentuk kesalahan yang paling sering dilakukan adalah kesalahan memahami permasalahan, pada kelompok sedang adalah kesalahan keterampilan proses, dan pada kelompok tinggi adalah kesalahan penulisan jawaban.
\end{abstract}

Kata kunci: interpolasi, analisis kesalahan newman, kemampuan pemecahan masalah

\begin{abstract}
Interpolation is a numerical method used to predict an unknown data value. Interpolation material is very important to be mastered well by students, especially to support research activities in working on the final project. To find out the effectiveness of interpolation learning during this pandemic, one way is to do an error analysis. Through error analysis, lecturers know the forms of errors that are most often made by students, so that they can be taken into consideration for implementing more effective learning strategies. The research method used is a qualitative method with a descriptive approach through analysis of the results of student answers to the questions of the Mid-Semester Examination. The research subjects were students of the mathematics education study program at the Suryakancana University FKIP who taught the numerical methods course for the academic year 2020 - 2021. The number of students who were the research subjects were 20 people. The result of this research is process skill error is the most frequent form of error, reaching $71 \%$ based on the Newman error analysis stage. In the group that has low problem-solving ability, the most common form of error is misunderstanding the problem, in the medium group it is a process skill error, and in the high group it is an error in writing answers.
\end{abstract}

Keywords: interpolation, newman error analysis, problem-solving ability 


\section{PENDAHULUAN}

Metode numerik merupakan cabang ilmu matematika yang sangat berkaitan erat dengan perkembangan teknologi saat ini. Berbagai permasalahan dalam perkembangan teknologi yang muncul, sering kali dapat dimodelkan dalam suatu persamaan matematika (Zuliyanti \& Pujiastuti, 2020). Jika persamaan yang terbentuk cukup sederhana maka pencarian solusi dapat dilakukan secara analitik, akan tetapi jika persamaan yang terbentuk cukup kompleks maka diperlukan metode numerik untuk menyelesaikannya. Karakteristik metode numerik yang menunjang hal tersebut adalah algoritma penyelesaian masalah dalam metode numerik dapat diaplikasikan dalam dunia komputasi. Dengan bantuan komputer maka metode numerik akan mampu menyelesaikan berbagai permasalahan matematika dengan lebih efektif dan efisien. Menurut Geetha dan Sekar "Numerical methods are rapidly moving into the mainstream of mathematics mainly because of its applications in diverse fields which include chemistry, electrical engineering, operation research" (Geetha \& Sekar, 2017). Hal ini menegaskan bahwa metode numerik merupakan mata kuliah yang penting untuk dikuasai oleh mahasiswa karena aplikasinya dalam berbagai bidang.

Dalam dunia pendidikan, khususnya di pendidikan matematika Universitas Suryakancana, metode numerik merupakan salah satu mata kuliah yang wajib diampu oleh mahasiswa. Metode numerik merupakan teknik penyelesaian masalah yang diformulasikan secara matematis dengan menggunakan operasi matematika dasar (tambah, kurang, kali, dan bagi). Salah satu manfaat mempelajari metode numerik bagi mahasiswa adalah sebagai sarana untuk memperkuat kembali pemahaman matematikanya, hal ini dikarenakan metode numerik ditemukan dengan menyederhanakan konsep matematika yang lebih tinggi menjadi operasi matematika dasar (Munir, 2015).

Salah satu materi yang dipelajari dalam metode numerik adalah Interpolasi. Dalam materi ini, mahasiswa mempelajari cara memprediksi suatu nilai data yang tidak diketahui dengan cara melakukan interpolasi terhadap data-data yang diketahui. Tidak sedikit mahasiswa dalam melakukan penelitian tugas akhir dihadapkan pada data yang tidak lengkap, seperti ketika menggunakan tabel-tabel statistika. Sehingga dengan menguasai materi interpolasi akan membantu kelancaran proses penelitian tersebut. Terdapat berbagai cara untuk melakukan interpolasi diantaranya menggunakan polinom derajat- $n$, polinom lagrange, dan polinom newton (Munir, 2015). Masing-masing cara tersebut memiliki karakteristik yang unik, sehingga diperlukan kemampuan matematis yang baik untuk dapat 
menggunakannya. Kemampuan matematis yang diperlukan yaitu kemampuan berpikir logis, kritis, sistematis, dan kreatif.

Selain kemampuan matematis yang baik, bentuk pembelajaran yang diterapkan sangat berpengaruh terhadap tingkat penguasaan materi oleh mahasiswa. Pada saat ini, dimana pandemi covid-19 belum berakhir, pembelajaran di pendidikan matematika Universitas Suryakancana dilakukan secara campuran (blended learning). Graham (2006) menyebutkan blended learning sebagai pembelajaran yang mengkombinasikan antara pembelajaran online dengan face-to-face (pembelajaran tatap muka). Untuk mengetahui efektifitasnya maka salah satu caranya perlu dilakukan analisis kesalahan atas hasil pembelajaran yang telah diterapkan. Analisis kesalahan merupakan suatu proses mereview jawaban siswa guna mengidentifikasi pola-pola ketidak-mengertian (Ketterlin-Geller \& Yovanoff, 2009).

Menurut Newman terdapat 5 tahapan analisis untuk melihat kesalahan seseorang dalam menyelesaikan suatu permasalahan matematis, yaitu: (1) tahap membaca (reading);

(2) tahap memahami (comprehension); (3) tahap transformasi (transformation); (4) tahap keterampilan proses (process skill); dan (5) tahap penulisan jawaban (encoding) (Darminto, 2019). Analisis kesalahan Newman (Newman's Error Analysis - NEA) memberikan kerangka untuk mempertimbangkan alasan yang mendasari tentang kesulitan yang dialami mahasiswa dalam menyelesaikan soal cerita matematis dan proses yang membantu dosen untuk menentukan dimana kesalahpahaman terjadi. NEA juga memberikan petunjuk bagi dosen kemana dosen mengarahkan strategi pengajaran yang efektif untuk mengatasinya (Karnasih, 2015).

Hal menarik yang akan diungkap dalam penelitian ini adalah apa bentuk kesalahan yang sering dilakukan pada setiap kelompok kemampuan mahasiswa. Terdapat tiga kelompok kemampuan mahasiswa yang akan dianalisis yaitu kemampuan rendah, sedang, dan tinggi. Dengan menganalisis setiap kelompok kemampuan, maka dosen dapat lebih mudah menentukan startegi pembelajaran yang efektif dan efisien untuk setiap kelompok kemampuan guna mencapai tujuan pembelajaran.

\section{Analisis Kesalahan Newman}

Metode analisis kesalahan Newman diperkenalkan pertama kali pada tahun 1977 oleh Anne Newman, seorang guru mata pelajaran matematika di Australia. Menurut Prakitipong \& Nakamura "The Newman Procedure is a method that analyzes errors in sentence problems“ (Prakitipong \& Nakamura, 2006). Berdasarkan keterangan tersebut 
kita peroleh informasi bahwa prosedur Newman adalah sebuah metode untuk menganalisis kesalahan dalam soal uraian. Newman menerbitkan data berdasarkan sistem yang dia kembangkan untuk menganalisis kesalahan yang dibuat pada tugas-tugas tertulis. Tahapan dalam analisis Newman yaitu membaca masalah (reading), memahami masalah (comprehension), transformasi masalah (transformation), keterampilan proses (process skill), dan penulisan jawaban akhir (encoding) (Karnasih, 2015).

\section{METODE PENELITIAN}

Metode penelitian yang digunakan termasuk ke dalam jenis penelitian deskriptif kualitatif, yaitu suatu metode penelitian yang memanfaatkan data kualitatif dan dijabarkan secara deskriptif. Dalam penelitian ini yang menjadi subjek penelitian adalah mahasiswa program studi pendidikan matematika FKIP Universitas Suryakancana yang mengampu mata kuliah metode numerik pada semester genap tahun akademik 2020 - 2021. Jumlah mahasiswa yang menjadi subjek penelitian sebanyak 20 orang.

Instrumen penelitian yang digunakan adalah Ujian Akhir Semester untuk soal interpolasi, berikut soal yang dimaksud:

Tabel Distribusi T

\begin{tabular}{crrrrr}
$\boldsymbol{v}$ & \multicolumn{4}{c}{$\boldsymbol{\alpha}$} \\
$\mathbf{1}$ & 63.6567 & 31.8205 & 12.7062 & 6.3138 \\
$\mathbf{2}$ & 9.9248 & 6.9646 & 4.3027 & 2.9200 \\
$\mathbf{3}$ & 5.8409 & 4.5407 & 3.1824 & 2.3534 \\
$\mathbf{4}$ & 4.6041 & 3.7469 & 2.7764 & 2.1318 \\
$\mathbf{5}$ & 4.0321 & 3.3649 & 2.5706 & 2.0150 \\
$\mathbf{6}$ & 3.7074 & 3.1427 & 2.4469 & 1.9432 \\
$\mathbf{7}$ & 3.4995 & 2.9980 & 2.3646 & 1.8946 \\
$\mathbf{8}$ & 3.3554 & 2.8965 & 2.3060 & 1.8595 \\
$\mathbf{9}$ & 3.2498 & 2.8214 & 2.2622 & 1.8331 \\
$\mathbf{1 0}$ & 3.1693 & 2.7638 & 2.2281 & 1.8125 \\
$\mathbf{1 1}$ & 3.1058 & 2.7181 & & 1.7959 \\
$\mathbf{1 2}$ & 3.0545 & 2.6810 & 2.1788 & 1.7823 \\
$\mathbf{1 3}$ & 3.0123 & 2.6503 & 2.1604 & 1.7709 \\
$\mathbf{1 4}$ & 2.9768 & 2.6245 & 2.1448 & 1.7613 \\
$\mathbf{1 5}$ & 2.9467 & 2.6025 & 2.1314 & 1.7531 \\
\hline & & & &
\end{tabular}

Perhatikan tabel di samping. Terdapat nilai tabel-t yang disembunyikan, kita sebut $T$, yaitu ketika $v=11$ dan $\alpha=0.025$. salah satu cara untuk mengestimasi nilai $T$ dapat dilakukan interpolasi. Oleh karena itu jawablah pertanyaan berikut ini:

1. Pilihlah titik data mana saja yang akan digunakan, jika Anda akan melakukan interpolasi polinom kuadrat, jelaskan jawaban Anda

2. Jika Anda menginterpolasi titik-titik data tersebut (yang diperoleh pada nomor 1) menggunakan interpolasi newton orde 2 , berapakah nilai $T$ yang didapat?

Capaian pembelajaran untuk materi interpolasi adalah mahasiswa mampu menerapkan konsep interpolasi untuk memecahkan permasalahan nyata. Pada soal yang diberikan kepada mahasiswa terlihat bahwa konten soal merupakan permasalahan nyata yang mungkin akan dihadapi mahasiswa dan mengharuskan mahasiswa untuk menyelesaikannya menggunakan konsep interpolasi. Dengan demikian instumen yang digunakan memiliki validitas isi yang baik.

Teknik analisis data yang dilakukan adalah pertama, melakukan telaah terhadap semua data yang terkumpul, dalam hal ini lembar jawaban mahasiswa, yang kemudian 
dijadikan dasar pengelompokan kemampuan mahasiswa. Kedua, melakukan analisis kesalahan yang dilakukan pada setiap kelompok kemampuan dengan cara mengkategorikan jenis kesalahan yang dilakukan. Terakhir, mendeskripsikan hasil analisis yang telah dilakukan agar mudah dipahami dan dapat dijadikan acuan dalam menentukan strategi pembelajaran yang tepat.

\section{HASIL DAN PEMBAHASAN}

Data penelitian yang didapatkan berupa jawaban soal dalam bentuk uraian. Selanjutnya dilakukan skoring untuk mengukur kemampuan pemecahan masalah mahasiswa dalam menjawab soal interpolasi. Perhatikan tabel berikut:

Tabel 1. Kelompok Kemampuan Pemecahan Masalah Mahasiswa

\begin{tabular}{|c|c|c|c|c|c|}
\hline Subjek & Skor & Kategori & Subjek & Skor & Kategori \\
\hline $\mathrm{m} 1$ & 50 & \multirow{10}{*}{ Rendah } & $\mathrm{m} 11$ & 70 & \multirow{8}{*}{ Sedang } \\
\hline $\mathrm{m} 2$ & 40 & & $\mathrm{~m} 12$ & 70 & \\
\hline $\mathrm{m} 3$ & 30 & & $\mathrm{~m} 13$ & 70 & \\
\hline $\mathrm{m} 4$ & 30 & & $\mathrm{~m} 14$ & 80 & \\
\hline $\mathrm{m} 5$ & 40 & & $\mathrm{~m} 15$ & 80 & \\
\hline $\mathrm{m} 6$ & 30 & & $\mathrm{~m} 16$ & 70 & \\
\hline $\mathrm{m} 7$ & 50 & & $\mathrm{~m} 17$ & 60 & \\
\hline $\mathrm{m} 8$ & 30 & & $\mathrm{~m} 18$ & 80 & \\
\hline $\mathrm{m} 9$ & 10 & & $\mathrm{~m} 19$ & 100 & \multirow{2}{*}{ Tinggi } \\
\hline $\mathrm{m} 10$ & 30 & & $\mathrm{~m} 20$ & 90 & \\
\hline
\end{tabular}

Dari tabel 1 terlihat hanya satu mahasiswa yang mendapatkan skor sempurna, yang berarti mahasiswa tersebut sudah memahami materi interpolasi dengan baik. Dari 19 mahasiswa yang tidak mendapatkan skor sempurna dapat dikatakan mereka melakukan kesalahan dalam proses menjawab soal yang diberikan. Berikutnya akan dilakukan analisis terkait bentuk kesalahan yang dilakukan mahasiswa berdasarkan pada analisis kesalahan Newman. Berapa banyak mahasiswa yang melakukan kesalahan berdasarkan teori Newman, perhatikan Gambar 1.

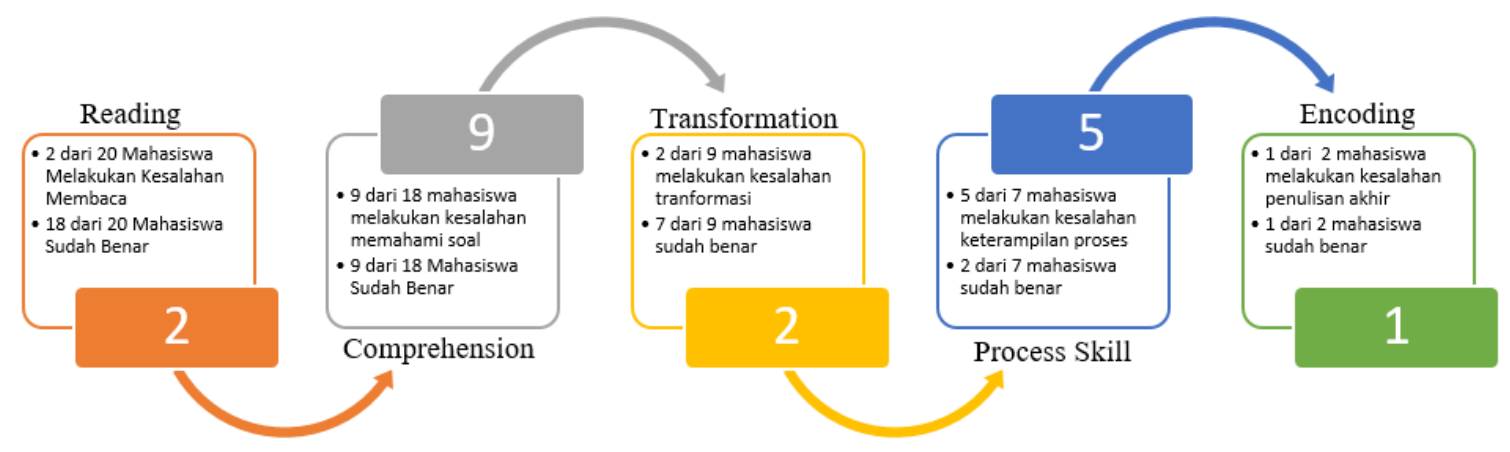

Gambar 1. Proses Analisis Kesalahan Newman 
Dari gambar 1 proses analisis kesalahan newman dapat dijelaskan sebagai berikut: pada tahap awal terdapat 2 mahasiswa yang melakukan kesalahan membaca, maka sisanya yaitu 18 mahasiswa tidak melakukan kesalahan. Kemudian dari 18 mahasiswa yang masuk ke tahap analisis kesalahan memahami, didapatkan 9 mahasiswa yang melakukan kesalahan, dan sisanya yaitu 9 mahasiswa tidak melakukan kesalahan. Berikutnya 9 mahasiswa yang masuk ke tahap analisis kesalahan transformasi didapatkan 7 mahasiswa sudah benar dan 2 mahasiswa melakukan kesalahan transformasi, dan seterusnya sampai dengan tahap penulisan akhir.

Jika dilakukan presentase kesalahan yang dilakukan mahasiswa pada setiap tahapnya, maka akan didapatkan diagram berikut

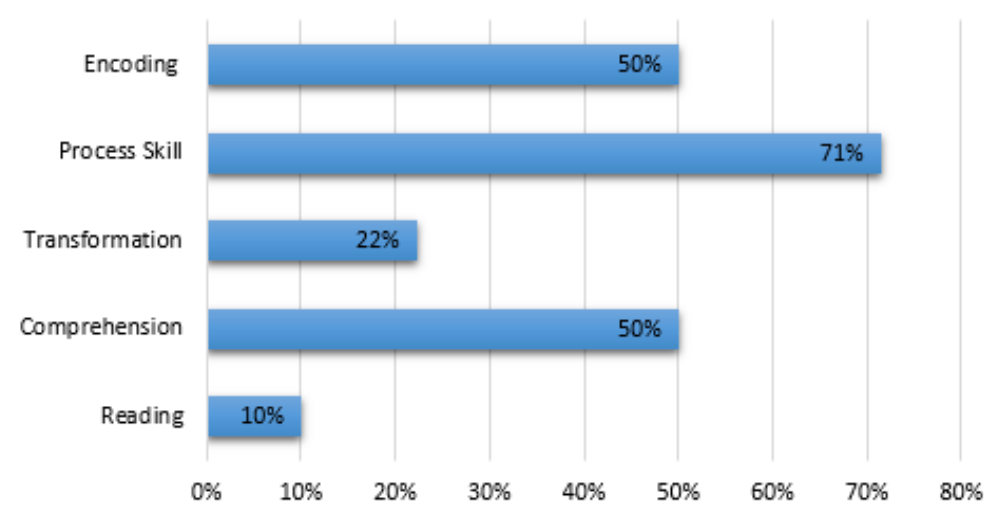

Gambar 2. Diagram Presentase Kesalahan

Dari diagram pada gambar 2 terlihat bahwa kesalahan keterampilan proses (process skill) merupakan bentuk kesalahan yang paling dominan dilakukan yaitu sebesar $71 \%$. Hal ini menandakan kemampuan melakukan perhitungan yang benar dari mahasiswa masih perlu ditingkatkan.

Selanjutnya akan dilakukan analisis kesalahan Newman terhadap tiap kelompok kemampuan untuk mengetahui bentuk kesalahan yang paling sering dilakukan oleh setiap kelompok. Pengelompokan dapat dilihat pada tabel 4.1 dan hasil analisis kesalahan newman adalah sebagai berikut: 


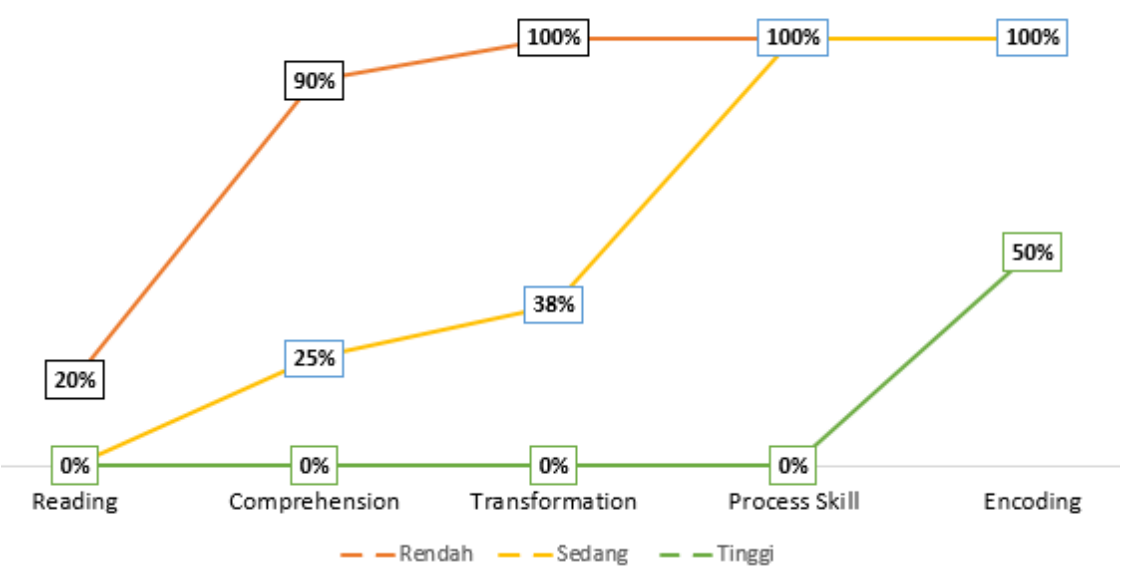

Gambar 3. Grafik Presentase Kesalahan Setiap Kelompok Kemampuan Pemecahan Masalah

Grafik pada gambar 3, dapat dijelaskan sebagai berikut:

- Pada kelompok mahasiswa yang termasuk memiliki kemampuan pemecahan masalah rendah terlihat peningkatan grafik yang sangat signifikan terjadi pada tahap kesalahan memahami, hal ini menunjukkan bahwa pada kelompok ini kesalahan memahami soal merupakan kesalahan yang paling sering dilakukan.

- Pada kelompok mahasiswa yang memiliki kemampuan pemecahan masalah sedang peningkatan signifikan terlihat pada kesalahan keterampilan proses, hal ini menunjukkan pada kelompok mahasiswa yang memiliki kemampuan pemecahan masalah sedang cenderung melakukan kesalahan pada tahap proses perhitungan dalam menemukan jawaban atau kesalahan keterampilan proses.

- Pada kelompok terakhir, yaitu mahasiswa yang memiliki kemampuan pemecahan masalah tinggi, kesalahan dilakukan ketika melakukan penulisan akhir atau dalam memberikan kesimpulan atas perhitungan yang dilakukan

\section{PEMBAHASAN}

\section{Kesalahan Membaca (Reading)}

Pada tahap reading, masih ada beberapa mahasiswa yang belum bisa membaca tabel pada soal yang diberikan.

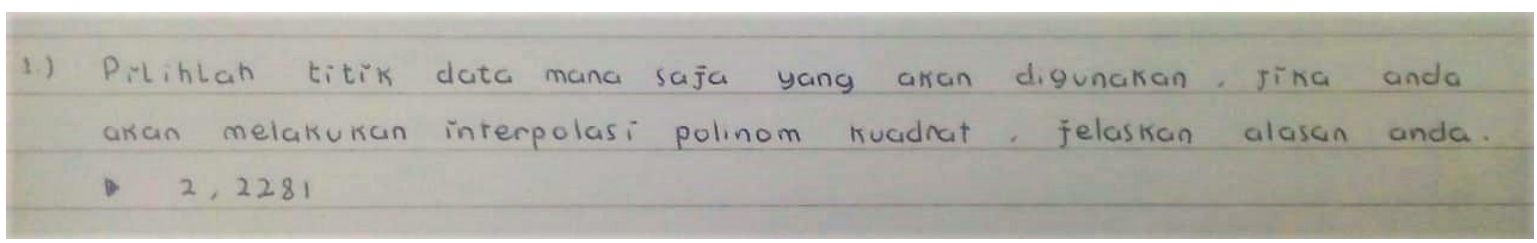

Gambar 4. Contoh kesalahan membaca

Kesalahan membaca terjadi ketika mahasiswa tidak mampu memaknai arti setiap kata, istilah, dan simbol dalam soal (Ganik Wahyuningtias Sunardiningsih, Hariyani, \& Fayeldi, 
2019). Dari gambar 4, terlihat bahwa mahasiswa hanya menjawab berupa satu nilai saja, padahal dalam melakukan interpolasi yang dimaksud titik adalah berupa pasangan terurut, misalkan $(2,2281,10)$. Hal ini dapat dijadikan gambaran bahwa selain tidak mampu membaca tabel yang diberikan, mahasiswa terlihat tidak memahami materi dengan baik. Dalam penelitian yang dilakukan Toha, dkk, didapatkan bahwa sebanyak 22,16\% peserta didik melakukan kesalahan jenis ini (Toha, Mirza, \& Ahmad, 2018). Sedangkan dalam penelitian ini, kesalahan membaca terjadi pada $10 \%$ peserta didik. Dengan persentasi di atas $10 \%$, tentu saja hal ini perlu menjadi perhatian, dikarenakan ketika peserta didik melakukan kesalahan membaca, maka langkah penyelesaian berikutnya menjadi tidak berarti atau akan bernilai salah. Faktor penyebab terjadinya kesalahan membaca adalah karena peserta didik tidak mampu memaknai arti simbol pada soal dan pada jawaban yang mereka berikan (Sari, Ferdiani, \& Yuwono, 2018).

\section{Kesalahan Memahami (Comprehension)}

Pada analisis kesalahan tahap pemahaman, cukup banyak mahasiswa yang belum memahami permasalahan dengan benar. Bentuk contoh kesalahan memahami dapat dilihat pada gambar 5. Terlihat mahasiswa tidak memahami materi tentang interpolasi polinom kuadrat. Untuk melakukan interpolasi polinom kuadrat maka titik data yang dibutuhkan adalah 3 buah, sedangkan jawaban mahasiswa ini memberikan 4 buah titik data. Walaupun kesalahan yang dilakukan tidak terlalu fatal, hal ini cukup menggambarkan bahwa mahasiswa tersebut tidak memahami materi yang menjadi pertanyaan dalam soal tersebut.

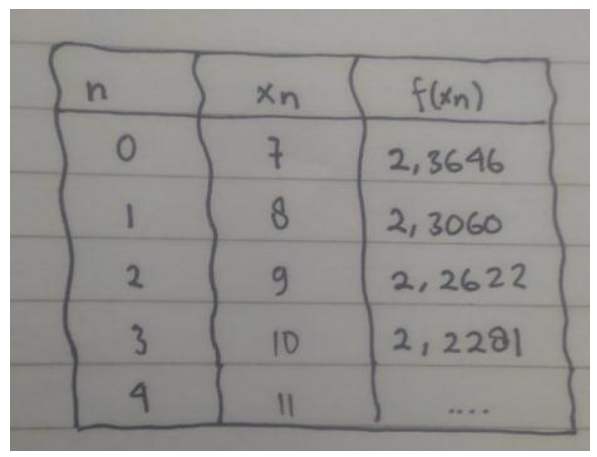

Gambar 5. Contoh Kesalahan Memahami Permasalahan

Kemampuan pemahaman memiliki hubungan positif terhadap kemampuan pemecahan masalah (Hartati, Abdullah, \& Haji, 2017). Dari mahasiswa yang tidak melakukan kesalahan membaca, didapatkan 55\% mahasiswa melakukan kesalahan memahami. Dengan kata lain lebih dari setengah mahasiswa melakukan kesalahan jenis ini. Hal ini memberikan gambaran bahwa kemampuan pemahaman mahasiswa masih 
rendah. Hal ini sejalan dengan penelitian yang dilakukan oleh Susiaty,dkk yang melakukan penelitian terkait kemampuan pemahaman matematis di SMP dimana didapatkan bahwa kemampuan pemahaman siswa masih rendah yang ditunjukkan dengan terdapatnya kekeliruan dalam penyelesaian soal perbandingan (Susiaty \& Haryadi, 2019).

\section{Kesalahan Transformasi (Transformation)}

Dalam tahap ini, agar tidak melakukan kesalahan mahasiswa perlu mengetahui dan memahami beberapa teknik interpolasi yang sudah diajarkan.

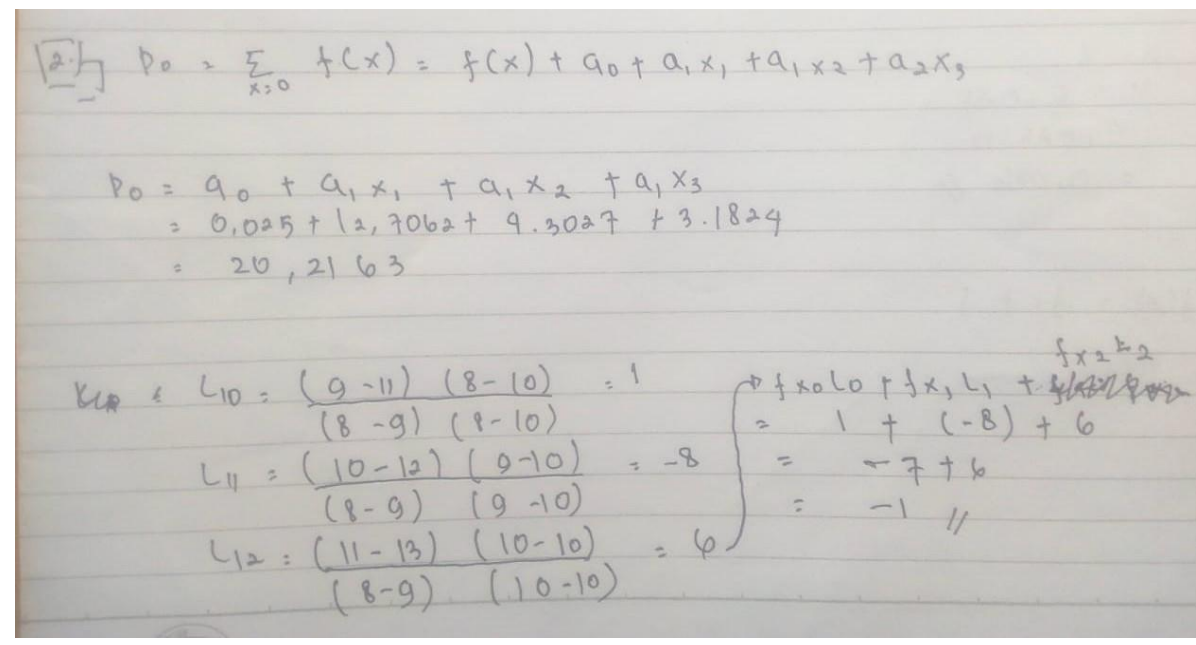

Gambar 6. Contoh Kesalahan Transformasi

Jawaban mahasiswa pada gambar 6, formula yang digunakan bukanlah interpolasi newton orde 2 melainkan interpolasi lagrange. Sehingga dapat disimpulkan bahwa mahasiswa tersebut melakukan kesalahan transformasi karena salah memilih rumus yang benar atau yang sesuai dengan pertanyaan (Suyitno \& Suyitno, 2015). Dalam penelitian ini, didapatkan bahwa sebanyak 25\% dari mahasiswa yang tidak melakukan kesalahan membaca dan kesalahan memahami telah melakukan kesalahan transformasi. Hal ini menggambarkan jenis kesalahan transformasi tidak terlalu sering dilakukan oleh mahasiswa. Penyebab terjadinya kesalahan transformasi adalah karena peserta didik tidak tahu rumus yang harus digunakan (Murtiyasa \& Wulandari, 2020).

\section{Kesalahan Keterampilan Proses (Process Skill)}

Pada tahap analisis kesalahan keterampilan proses, sebanyak 71\% mahasiswa masih melakukan kesalahan. 




Gambar 7. Contoh Kesalahan Keterampilan Proses

Kesalahan yang dilakukan oleh mahasiswa pada gambar 7 adalah pada pencarian nilai a. Seharusnya dalam mencari nilai a menggunakan cara berikut $a=(1,8331-1,8595) /(9-8)=-0,0264$

Dalam penelitian ini, jenis kesalahan keterampilan proses merupakan jenis kesalahan yang paling sering dilakukan. Hal ini sesuai dengan penelitian yang dilakukan oleh Rismawati, M dan Asnayani, M yang menyatakan bahwa "Kesalahan yang paling dominan dilakukan peserta didik adalah kesalahan keterampilan proses karena peserta didik kurang teliti dan kurang terampil dalam berhitung" (Rismawati \& Asnayani, 2019). Beberapa solusi untuk mengatasi kesalahan keterampilan proses adalah meminta mahasiswa untuk mengecek kembali hasil pengerjaan dan menanamkan pentingnya pemahaman membaca soal cerita dengan seksama (Firdaus, 2017; Rohmah, Septian, \& Inayah, 2020; Widiyawati, Septian, \& Inayah, 2020).

\section{Kesalahan Penulisan Akhir (Encoding)}

Pada tahap ini presentase mahasiswa yang melakukan kesalahan sesuai tahap Newman adalah 50\%. Indikator kesalahan pada jenis kesalahan penulisan akhir adalah peserta didik tidak dapat menunjukkan jawaban yang benar (Hikmawati, Nurcahyono, \& Balkist, 2019; Suyitno \& Suyitno, 2015). Selain itu, indikator lain adalah peserta didik melakukan kesalahan dalam mengubah hasil akhir ke dalam kalimat kontekstual atau 
membuat kesimpulan (Rismawati \& Asnayani, 2019). Perhatikan contoh jawaban mahasiswa berikut:

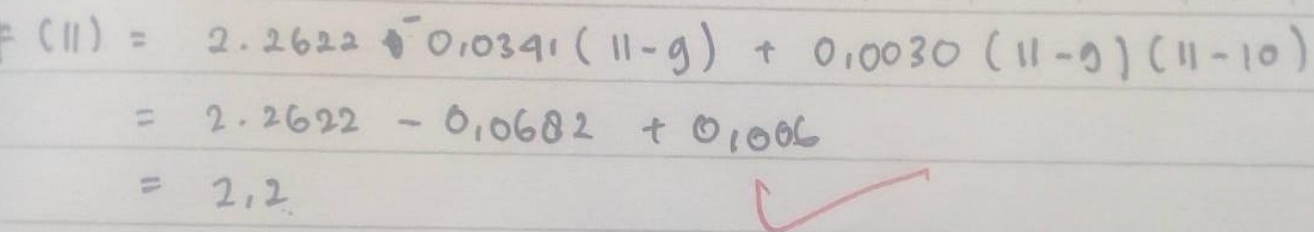

Gambar 8. Contoh Kesalahan Penulisan Akhir

Pada gambar 8 terlihat bahwa mahasiswa hanya mencukupkan pengerjaan soal pada proses perhitungan saja, tanpa memberikan kesimpulan akhir yang menjawab pertanyaan. Faktor penyebab peserta didik melakukan kesalahan ini adalah karena peserta didik tidak terbiasa untuk memberikan jawaban yang lengkap (Islamiyah, Prayitno, \& Amrullah, 2018). Oleh karena itu, solusi yang bisa diberikan untuk mengurangi jenis kesalahan ini adalah membiasakan peserta didik untuk menjawab soal dengan lengkap.

\section{KESIMPULAN}

Berdasarkan hasil analisis kesalahan terhadap data penelitian yang telah diuraikan maka didapat beberapa hal berikut:

1. Berdasarkan tahapan analisis kesalahan Newman, didapatkan bentuk kesalahan yang paling dominan dilakukan mahasiswa dalam menjawab soal adalah kesalahan keterampilan proses yang mencapai $71 \%$. Bentuk kesalahan ini mengindikasikan bahwa mahasiswa masih cukup sering melakukan salah perhitungan sehingga akibatnya salah dalam mengambil kesimpulan.

2. Berdasarkan analisis kemampuan pemecahan masalah didapat 50\% mahasiswa termasuk memiliki kelompok yang memiliki kemampuan pemecahan masalah yang rendah, 40\% kelompok sedang, dan 10\% kelompok tinggi.

3. Bentuk kesalahan yang sering dilakukan pada kelompok rendah adalah kesalahan memahami permasalahan, pada kelompok sedang adalah kesalahan keterampilan proses, dan pada kelompok tinggi adalah kesalahan penulisan akhir atau menuliskan kesimpulan yang menjawab soal.

Saran yang dapat diberikan dalam peningkatan proses pembelajaran dalam materi interpolasi adalah adanya penekanan pada pemahaman materi dan soal serta membiasakan mahasiswa dalam membaca tabel data. Dalam upaya meningkatkan keterampilan proses maka perlu ditekankan pada mahasiswa untuk selalu mengecek kembali jawaban yang 
sudah didapat. Sedangkan untuk mengurangi kesalahan pada penulisan akhir adalah dengan membiasakan mahasiswa untuk selalu menuliskan jawaban secara lengkap.

\section{REFERENSI}

Darminto, B. P. (2019). Analisis kesalahan mahasiswa dalam menyelesaikan soal sistem persamaan non-linear berdasarkan teori newman. Prosiding Sendika, 5(1), 1-5.

Firdaus, H. P. E. (2017). Analisis kesalahan mahasiswa dalam menyelesaikan masalah matematika berdasarkan gaya belajar. Prosiding Konferensi Nasional Penelitian Matematika Dan Pembelajarannya (KNPMP) II, 501-511. Universitas Muhammadiyah Surakarta.

Ganik Wahyuningtias Sunardiningsih, Hariyani, S., \& Fayeldi, T. (2019). Analisis kesalahan siswa dalam menyelesaikan soal matematika berdasarkan analisis newman. Rainstek: Jurnal Terapan Sains Dan Teknologi, 1(2), 41-45.

Geetha, N. K., \& Sekar, P. (2017). Numerical Methods - Engineering Applications. International Journal of ChemTech Research, 10(10).

Hartati, S., Abdullah, I., \& Haji, S. (2017). Pengaruh kemampuan pemahaman konsep, kemampuan komunikasi dan koneksi terhadap kemampuan pemecahan masalah. MUST: Journal of Mathematics Education, Science and Technology, 2(1).

Hikmawati, N. N., Nurcahyono, N. A., \& Balkist, P. S. (2019). KEMAMPUAN komunikasi matematis siswa dalam menyelesaikan soal geometri kubus dan balok. PRISMA, 8(1), 68. https://doi.org/10.35194/jp.v8i1.648

Islamiyah, A. C., Prayitno, S., \& Amrullah. (2018). Analisis kesalahan siswa SMP pada penyelesaian masalah sistem persamaan linear dua variabel. Jurnal Didaktik Matematika, 5(1), 66-76.

Karnasih, I. (2015). Analisis kesalahan newman pada soal cerita matematis. Jurnal PARADIKMA, 8(April), 37-51.

Ketterlin-Geller, L. R., \& Yovanoff, P. (2009). Diagnostic assessments in mathematics to support instructional decision making. In Practical Assessment, Research \& Evaluation (Vol. 14).

Munir, R. (2015). Metode Numerik (Revisi 4). Bandung: INFORMATIKA.

Murtiyasa, B., \& Wulandari, V. (2020). Analisis kesalahan siswa materi bilangan pecahan berdasarkan teori newman. AKSIOMA: Jurnal Program Studi Pendidikan Matematika, 9(3). https://doi.org/https://doi.org/10.24127/ajpm.v9i3.2795

Prakitipong, N., \& Nakamura, S. (2006). Analysis of mathematics performance of grade five students in Thailand using newman procedure. Journal of International Cooperation in Education, 9(1).

Rismawati, M., \& Asnayani, M. (2019). Analisis kesalahan konsep siswa dalam menyelesaikan soal ulangan matematika dengan metode newman. J-PiMat, 1(2), 6978.

Rohmah, W. N., Septian, A., \& Inayah, S. (2020). Analisis kemampuan penalaran matematis materi bangun ruang ditinjau gaya kognitif siswa menengah pertama. PRISMA. https://doi.org/10.35194/jp.v9i2.1043

Sari, L. N. I., Ferdiani, R. D., \& Yuwono, T. (2018). Analisis kesalahan dalam menyelesaiakan soal cerita berdasarkan teori newman. Ibriez: Jurnal Kependidikan Dasar Islam Berbasis Sains, 1(3), 100-106.

Susiaty, U. D., \& Haryadi, R. (2019). Analisis kemampuan pemahaman matematis siswa dalam menyelesaikan soal perbandingan di kelas VII SMP. Jurnal Pendidikan Informatika Dan Sains, 8(2), 239. https://doi.org/10.31571/saintek.v8i2.1574 
Suyitno, A., \& Suyitno, H. (2015). Learning therapy for students in mathematics communication correctly based-on application of newman procedure (a case of Indonesian student). International Journal of Education and Research, 3(1).

Toha, M., Mirza, A., \& Ahmad, D. (2018). Analisi kesalahan siswa dalam menyelesaikan soal cerita materi perbandingan di kelas VII SMP. Jurnal Pendidikan Dan Pembelajaran Khatulistiwa, 7(1).

Widiyawati, W., Septian, A., \& Inayah, S. (2020). Analisis kemampuan koneksi matematis siswa SMK pada materi trigonometri. Jurnal Analisa, 6(1), 28-39. https://doi.org/10.15575/ja.v6i1.8566

Zuliyanti, P., \& Pujiastuti, H. (2020). Model contextual teaching learning (CTL) untuk meningkatkan kemampuan pemecahan masalah matematis siswa SMP. Prisma, 9(1), 98. https://doi.org/10.35194/jp.v9i1.899 